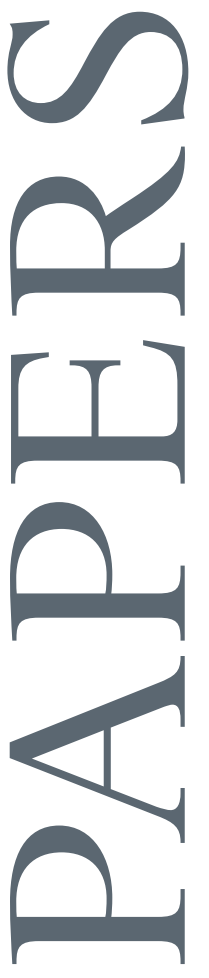

EAST-WEST CENTER WORKING PAPERS

Environment, Population, and Health Series

No. 7, June 2015

\title{
Age Structure and Trade Openness: An Empirical Investigation
}

Yukio Fukumoto and Tomoko Kinugasa

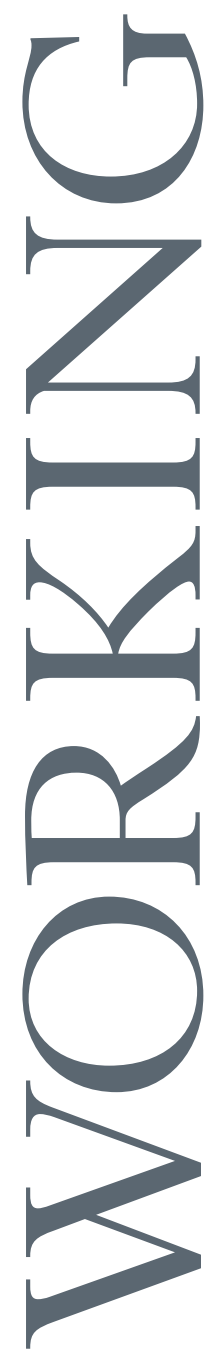

VE $\frac{\text { E A S T - W E S T C E N T E R }}{\text { Collaboration - Expertise - Leadership }}$ 


\title{
Age Structure and Trade Openness: An Empirical Investigation
}

\author{
Yukio Fukumoto and Tomoko Kinugasa
}

Yukio Fukumoto is an Associate Professor of Economics at the Osaka University of Economics, Japan. He was a visiting scholar at the East-West Center from August 2013 to August 2014.

East-West Center Working Papers is an unreviewed and unedited prepublication series reporting on research in progress. The views expressed are those of the author and not necessarily those of the Center. East-West Center Working Papers are circulated for comment and to inform interested colleagues about work in progress at the Center.

Working Papers are available online for free at EastWestCenter.org/ewcworkingpapers.

The East-West Center promotes better relations and understanding among the people and nations of the United States, Asia, and the Pacific through cooperative study, research, and dialogue. Established by the US Congress in 1960, the Center serves as a resource for information and analysis on critical issues of common concern, bringing people together to exchange views, build expertise, and develop policy options.

The Center's 21-acre Honolulu campus, adjacent to the University of Hawai'i at Mānoa, is located midway between Asia and the US mainland and features research, residential, and international conference facilities. The Center's Washington, DC, office focuses on preparing the United States for an era of growing Asia Pacific prominence.

The Center is an independent, public, nonprofit organization with funding from the US government, and additional support provided by private agencies, individuals, foundations, corporations, and governments in the region.

\section{EastWestCenter.org/publications}

Publications Office| East-West Center 1601 East-West Road | Honolulu, Hawai'i 96848-1601

Tel: 808.944.7145 | Fax: 808.944.7376

EWCBooks@EastWestCenter.org
Tomoko Kinugasa is an Associate Professor of Economics at the Kobe University, Japan. She was a visiting scholar at the East-West Center from August 2013 to August 2014.

This paper is a revised version of the paper, "Trade Openness and Demographic Change," presented at the brown bag seminar of the East-West Center in Honolulu, Hawai'i, on August 19, 2014. 


\title{
Age structure and trade openness: An empirical investigation*
}

\author{
Yukio Fukumoto ${ }^{\dagger}$ \\ Department of Economics, Osaka University of Economics \\ Tomoko Kinugasa \\ Graduate School of Economics, Kobe University
}

June 1, 2015

\begin{abstract}
This research focuses attention on the relationship between age structure and trade openness. We hypothesized that a higher working-age population share of a total population raises trade openness because dependent population tend to spend more than working-age population for non-tradable goods such as education and medical services. We estimated the effects of age structure on trade openness empirically using panel data of 85 countries from 1991 to 2010, and we simulated trade openness based on changes in age structure from 1991 to 2100 . The estimation results show that an increase in the share of working-age (dependent) population in a total population has a positive (negative) effect on trade openness. According to the simulation results, an increase in the share of the workingage population will increase trade openness until the beginning of the 21 st century.

However, the turnover of the share of the working-age population and more rapid increase in the share of the old-dependent population will decrease trade openness after that.

JEL classification: F14, F41, J11

Key words: Trade openness, age structure, tradable goods, non-tradable goods, simulation

\footnotetext{
* This paper is revised version of the paper, “Trade Openness and Demographic Change," presented at the Brown Bag Seminar of the East-West Center in Honolulu, Hawaii, the United States on August 19, 2014. The authors were visiting scholars at the East-West Center from August 2013 to August 2014 and benefited from discussions with Professor Andrew Mason during the period. We appreciate valuable comments from Professor Mason about this research. This work was supported by JSPS KAKENHI Grant Numbers 26292118 and 24310031.

† fukumoto@osaka-ue.ac.jp, corresponding author.
} 


\section{Introduction}

The network of international trade was destroyed once by World War II, but by the end of the 20th century international trade had developed remarkably. The scale of recent international trade is prominent historically. Bordo (2002, p. 22) noted that "by the 1970s, the ratio of trade to GDP reached the levels of the earlier age of globalization". ${ }^{1}$ International trade continues to develop in the 21 st century. Figure 1 illustrates the trade openness (i.e., the ratio of trade to GDP) in the world from 1950 to 2010. Trade openness was stagnant until the 1960s and has increased since the 1970s. We infer from these data that there are common factors in the increase in trade openness in the world because the trade openness of many countries — not a limited number of countries — has seemed to rise.

\section{$<$ Insert Figure $1>$}

The remarkable development of international trade since the 1970s and the reasons for this development have attracted the attention of many economists. For example, Krugman (1995) insisted that the main reason is a decline in trade barriers such as policy-led trade liberalization and technology-led falling transportation costs. From the historical viewpoint, tariff rates decreased dramatically in the latter half of the 20th century although the

\footnotetext{
${ }^{1}$ The earlier age of globalization usually means the period from the mid-nineteenth century until 1914.
} 
available data are restricted to advanced countries. ${ }^{2}$ After World War II, the General Agreement on Tariffs and Trade (GATT), the World Trade Organization (WTO), and various Free Trade Agreements (FTAs) played an important role in decreasing the tariff rates. ${ }^{3}$ Moreover, information and communication technology as well as transportation technology developed greatly after WWII, and these decreased transportation costs. Feenstra (1998) focused on factors other than trade barriers and proposed that foreign outsourcing accompanied by a breakdown in the vertically integrated mode of production is one cause of the development of international trade since the 1970s.

In this research we empirically investigate whether age structure has influenced trade openness. Many macroeconomists and demographers have analyzed the effects of age structure on saving, investment, production, consumption, current account balance, trade balance and real exchange rate. ${ }^{4}$ However, previous studies have not adequately discussed the effects of age structure on trade openness, and it is worthwhile to discuss this issue. If

${ }^{2}$ For example, see Bordo (2002, Figure 2).

${ }^{3}$ There were the 128 GATT signatories at the end of 1994. The WTO was the subsequent institute of the GATT. Seventy-seven countries were involved in the WTO when it was established on January 1, 1995, and the number of member countries involved in the WTO increased to 160 by 2014. FTAs between two countries or within a particular area have also developed rapidly since the 1990s, and most countries have already concluded FTAs with several countries.

${ }^{4}$ Modigliani and Brunberg (1954) is the primary research in this field, and they proposed the lifecycle hypothesis. Many studies such as Fry and Mason (1982), Mason (1987, 1988), Fair and Dominguez (1991), Taylor and Williamson (1994), Taylor (1995), Lindh and Malmberg (1998, 1999), Poterba (2001) and Kinugasa and Mason (2007) have considered the relationship between age structure and macroeconomic fundamentals. 
age structure contributes to the development of international trade, it will be necessary to think about international trade policies considering age structure. Moreover, we can obtain clues about the future trade openness from the future projected age structure by determining the effects of age structure on trade openness. We suggested that age structure influences trade openness based on differences in the share of the consumption of tradable goods between working-age and dependent populations. Tradable goods are goods that can be traded with foreign counties, and non-tradable goods are goods that are produced and consumed domestically. Compared to working-age individuals, dependent individuals tend to consume more childcare, education, nursing care and medical services. Such services are mainly non-tradable goods, and this indicates that working-age population spend relatively more on tradable goods than dependent population do, and that an increase in the share of working-age (dependent) population will increase the demand and supply for tradable goods (non-tradable goods). Not all tradable goods are imported (exported), but an increase in the demand (supply) for tradable goods will increase imports (exports). It is thus plausible that an increase in the share of working-age (dependent) population will increase (decrease) trade openness due to the difference in the consumption structure. ${ }^{5}$

\footnotetext{
${ }^{5}$ It has been shown indirectly that age structure influences trade balance. Previous studies such as Herbertsson and Zoega (1999) and Higging (1998) insisted that age structure influences the current account because the current account is expressed as saving minus investment and age structure influences saving and investment. The current account is also the sum of the net exports of goods and services, the net primary income, and the net secondary income; i.e., the trade balance is a part of the current account. For example, the trade balance is not very different from the current account in the United States (Hill 1989,
} 
The expansion of trade openness since the 1970s does not seem to contradict our hypothesis about the effects of age structure on trade openness. Figure 2 shows the world's age structure from 1950 to 2100 reported and predicted by the United Nations. From 1950 to 2010 , the share of the world's old-dependent population was small and did not change greatly, whereas the shares of the young-dependent population and the working-age population were large and changed remarkably. The share of the young-dependent population peaked in the 1960s and decreased afterward. The share of the working-age population decreased in the 1950s and 1960s and has increased since the 1970s. It appears that the trade openness shown in Figure 1 and the share of the working-age population in Figure 2 have similar characteristics, and therefore, age structure is one possible factor contributing to trade openness. Figure 2 also shows that the age structure for the entire world has been facing a turning point since around 2010. The share of the world's workingage population is expected to peak in the 2010s and then decrease. The share of the olddependent population has increased since 1950, and the speed of the increase has risen since 2010. In fact, the United Nations (2013a) pointed out that more and more countries have shown interest in low fertility and longer life. ${ }^{6}$ It is expected that age structure will be

foot note 2 and Ferrero 2010, foot notes 1 and 13), and it is possible that age structure influences trade balance. However, there is not necessarily a stable relationship between exports plus imports and exports minus imports. Therefore, even if age structure and trade balance are related, it does not mean that age structure and trade openness are related. ${ }^{6}$ See the United Nations (2013a, Chapters II and III). Lee et al. (2014) insisted that rapid population aging induced by low fertility and longer lives in many countries in the beginning of the 21 st century influenced living standards, and they analyzed the effects of 
one of the reasons for a decrease in trade openness in the future even if age structure is currently one of the reasons for an increase in trade openness.

\section{$<$ Insert Figure 2 >}

Rodrik (1998) and Benarroch and Pandey (2008) examined the relationship between age structure and trade openness. Rodrik (1998) conducted an empirical analysis setting the growth rate of trade openness as a dependent variable and including the logarithm of the dependency ratio in the independent variables (Rodrik 1998, Table 1). In the empirical analysis by Benarroch and Pandey (2008), the dependent variable is the logarithm of trade openness and independent variables include the logarithm of one period lagged government size and the logarithm of the dependency ratio (Benarroch and Pandey 2008, Table 2). The empirical results obtained by Rodrik (1998) could clarify whether age structure accelerated the increase in trade openness, but they do not clarify our hypothesis. ${ }^{7}$ Benarroch and Pandey (2008) analyzed the causal relationship between government size and trade openness, but the effect of the dependency ratio on trade openness was not reported and the variable of age structure was considered to be just one of the control variables. Thus the focuses of Rodrik (1998) and Benarroch and Pandey (2008) are different from our research.

changes in fertility on living standards using their own methodology, called the National Transfer Accounts.

${ }^{7}$ The empirical results of Rodrik (1998) show that the estimate is positive but not significant. 
After all, Rodrik (1998) and Benarroch and Pandey (2008) did not clearly describe how the dependency ratio influences trade openness.

What we do in this research is summarized as follows. First, we empirically analyze whether age structure influences trade openness using the panel data of 85 countries from 1991 to 2010. In the analysis, we also consider several factors suggested in previous studies to influence trade openness. Our empirical results show that an increase in the share of the working-age (dependent) population in a total population raises (lowers) trade openness. Second, we simulate trade openness based on changes in age structure from 1991 to 2100. According to our simulated results, age structure will increase trade openness until the share of the working-age population reaches a peak in the first half of the 21 st century. After that, age structure will decrease trade openness.

\section{Relationship between age structure and trade openness}

In this section, we discuss the relationship between age structure and trade openness. The idea of Braude (2000) could be useful in explaining how age structure influences trade openness. He contended that there is a relationship between age structure and real exchange rate. According to Braude (2000), people of different ages consume different kinds of goods and services, and thus the shares of the working-age population and the dependent population in the total population of a country are important factors for the shares of tradable goods and non-tradable goods in total demand in the country.

Braude (2000) established an overlapping generations model that assumes a small open economy facing an exogenous price of tradable goods. He stated that the share of the 
consumption of non-tradable goods in the total consumption by dependent population tends to be higher than that by working-age population. ${ }^{8}$ Indeed, the consumption share of childcare and education expenditures are high for young-dependent population and the share of nursing care is high for old-dependent population. In addition, the share of medical expenditures for both young- and old-dependent populations can be high compared to working-age population. Childcare, education, nursing care and medical services are mostly non-tradable, and the share of dependent population will have a positive effect on the share of consumption for non-tradable goods. The model described by Braude (2000) suggests that an increase in the share of the dependent population in a total population raises the prices of non-tradable goods because the relative demand for non-tradable goods increases, causing an appreciation of the real exchange rate, which is the relative price of tradable goods and non-tradable goods. ${ }^{9}$

The effects of age structure on trade openness can be explained based on Braude (2000). An increase in the share of working-age population shifts non-tradable goods-

\footnotetext{
${ }^{8}$ Braude (2000, Section 3.1) used mainly the data of the United States around 1990 and showed that preferences between tradable goods and non-tradable goods for the different age groups are different.

${ }^{9}$ Based on Braude's (2000) model, Rose et al. (2009) found empirically that a country experiencing a rise in its fertility rate experienced a real appreciation. They also investigated the relationship between the real effective exchange rate and some other demographic measures, but they found that none was significantly different from the hypothesis of no effect at all. They proposed that the reason is because dramatic changes in these demographic measures have yet to emerge in the actual data, at least by comparison with the large changes in fertility ratios. See Rose et al. (2009, Section 7) for details.
} 
oriented demand structure to tradable goods-oriented demand structure and as a result, production can shift from non-tradable goods to tradable goods. Even if countries can produce all of the tradable goods by themselves, will they not do so. Theoretical studies of international trade have indicated that countries can derive mutual gains from international trade by specializing in the production of different tradable goods. ${ }^{10}$ Therefore, an increase in the share of a country's working-age population increases both the exports of tradable goods that are demanded in foreign countries and the imports of tradable goods that are produced in foreign countries.

\section{Model and Data}

Here we investigate whether age structure influences trade openness considering several factors suggested by previous studies to influence trade openness. We estimate the equation by using the fixed-effects model and the random-effects model. The dependent variable trade openness is defined as the ratio of the sum of exports and imports to GDP. We explain the independent variables as follows.

For the variable of Age structure, we use (1) the share of population from 15 to 64 years old in the total population; i.e., the working-age population share, (2) the share of population from 25 to 49 years old in the total population; i.e., the share of the working-age population that tends to be highly involved in productive activity, (3) the share of

\footnotetext{
${ }^{10}$ For details about inter-industry trade based on comparative advantage, see Dornbusch et al. (1977) and Davis (1995). Krugman (1979) and Helpman (1981) described the model of intra-industry trade based on increasing returns to scale and imperfect competition.
} 
population from 0 to 14 years old; i.e., the share of young-dependent population, and (4) the share of population of 65 years and older; i.e., the share of the old-dependent population. We consider these two types of prime age population because the ages from 15 to 24 include the years of secondary and tertiary education and because the mandatory retirement age is under 64 in some countries. We analyze the young- and old-dependent populations separately because the degrees of demand for non-tradable goods may be different between young- and old-dependent populations. Braude (2000) indicated that young generation tends to consume non-tradable goods more intensively than old generation. ${ }^{11}$ Based on the discussion in Section 2, we expect that the shares of the working-age population and the population from 25 to 49 years old have positive effects on trade openness, and that those of the young- and old-dependent populations have negative effects on trade openness.

We include Government size as an independent variable. Government size is defined as the share of government consumption in GDP. Cameron (1978) was the first to focus on the relationship between government size and trade openness. He suggested several channels through which an increase in trade openness increases government size (Cameron 1978, Figure 3). Alesina and Wacziarg (1998) and Rodrik (1998) supported Cameron

\footnotetext{
${ }^{11}$ The lifecycle hypothesis implies that an increase in the share of working-age (dependent) population increases (decreases) the saving rate. However, many empirical studies reported that an increase in the share of old-dependent population increased the saving rate similarly to working-age population, although an increase in the share of young-dependent population decreased the saving rate. It may thus be possible to draw the wrong conclusion when considering young- and old-dependent populations altogether. See Hurd (1990) for details.
} 
(1978) based on more detailed statistical investigations. However, their empirical results were pointed out as questionable by some researchers. Garrett (2001) supported the empirical results of Alesina and Wacziarg (1998) and Rodrik (1998) in terms of level but found that the growth rate of trade openness has a negative impact on the growth rate of government size (Garrett 2001, Tables 2 and 4). ${ }^{12}$ Benarroch and Pandey (2008) found that there is no causality from trade openness to government size, but they reported a negative causality from government size to trade openness (Benarroch and Pandey 2008, Table 2). ${ }^{13}$ They wrote that "one possible explanation for this may be that larger governments are more interventionist in the market. This higher level of intervention may apply to the foreign market so that countries with larger governments may be more protectionists and thus, less open" (Benarroch and Pandey 2008, p.159). ${ }^{14}$ It is therefore possible that government size affects trade openness.

${ }^{12}$ Garrett (2001, Section 2) indicated that there are two basic positions in the globalization and national autonomy debate. He labeled the conventional wisdom about globalization constraints on policy interventionism the efficiency hypothesis and the perspective about the incentives for government intervention in the face of domestic dislocations generated by globalization the compensation hypothesis.

${ }^{13}$ Some studies analyzed the effect of trade openness on macroeconomic fundamentals other than the government size. For example, Barro (2000) found that trade openness has a significant positive impact on income inequality.

${ }^{14}$ Garen and Trask (2005), Islam (2006), and Benarroch and Pandey (2012) also came to conclusions that differed from those of Cameron (1978), Rodrik (1998), and Alesina and Wacziarg (1998). 
We also consider Country size as a factor that affects trade openness. We use population for the variable of country size. Alesina and Wacziarg (1998, Tables 2 and 6) found that country size had a negative effect on trade openness. However, Ram (2009, Tables 2, 5, and 6) reexamined the research of Alesina and Wacziarg and found that country size had a negative effect on trade openness according to pooled ordinary leastsquares estimates but did not necessarily have a negative effect according to the fixedeffects estimates. ${ }^{15}$ Hence, the effect of country size on trade openness might be sensitive to model specifications. ${ }^{16}$

We use the tariff rate and period dummies mainly for the variable of Trade barriers. A decrease in the tariff rate will decrease trade barriers and promote international trade. We expect that the tariff rate has a negative effect on trade openness. Transportation cost is also one of the trade barriers, and technological change and energy price are main factors for a change in the transportation cost. ${ }^{17} \mathrm{~A}$ decline in the transportation cost can decrease trade

${ }^{15}$ Alesina and Wacziarg (1998, Section 2.1) discuss the argument that smaller countries should trade more. However, the linking country size and trade openness may not be simple matters. For example, see Helpman and Krugman (1985, Section 8) and Greenaway and Milner (1986, Section 7).

${ }^{16}$ Both Alesina and Wacziarg (1998) and Ram (2009) used not only population but also real GDP as a variable of country size and found that the results were not different to a great extent. We also used real GDP as the variable of the country size. The empirical results are described in footnote 27 in Section 4.

${ }^{17}$ Some researchers pointed out that the impact of transportation cost on trade openness has not been impressive in today's globalization. Baier and Bergstrand (2001, p. 3) wrote, "in the context of our theoretical model, tariff-rate reductions have had roughly three times the 
barriers for many countries in the same period, and thus it is reasonable that period dummy variables represent these factors.

We suspect that the foreign outsourcing suggested by Feenstra (1998) comprises part of the period dummy variables. It would be difficult to include proxy variables for foreign outsourcing because of the data restriction. Feenstra (1998) proposed that foreign outsourcing contributes to the expansion of world trade. If many countries — not a limited number of countries — are influenced by foreign outsourcing, the period dummies might capture the effect. ${ }^{18}$ Considering that a decrease in transportation cost and an increase in foreign outsourcing could contribute to an increase in trade openness, we expect that the period dummies have positive effects on trade openness. ${ }^{19}$

Our data sources are as follows. The variables for age structure are from World Population Prospects: The 2012 Revision, DVD Edition by the United Nations, Department impact upon the growth of world trade as transport-cost declines, other factors held constant.” Their empirical results supported this assertion (Baier and Bergstrand 2001, Section 5).

${ }^{18}$ If the effects of foreign outsourcing vary depending on the countries, the effects would be captured by the country dummies included in the fixed-effects model. The country dummies would also include information about the characteristics of each country such as geographical condition and language, which can influence trade.

${ }^{19}$ Global economic shocks are also considered to be incorporated into period dummies. As is shown in Figure 1, trade openness was stagnant in the latter half of the 2000s. One important reason could be the global economic crisis. However, Figure 2 shows that an increase in working-age population began to slow down in the latter half of the 2000s, and it is possible that age structure prevented increases in trade openness. 
of Economic and Social Affairs, Population Division. ${ }^{20}$ The tariff rate data are obtained from World Development Indicators, published by the World Bank. ${ }^{21}$ The data of other variables are obtained from Penn World Table 8.0. Government size is represented by the share of government consumption in GDP (Indicator Code: csh_g). Trade openness is calculated as the sum of the absolute values of the share of merchandise exports in GDP (Indicator Code: csh_x) and the share of merchandise imports in GDP (Indicator Code: csh_m). ${ }^{22}$ Population is expressed in millions (Indicator Code: pop). We deal with a sample period from 1991 to 2010 and divide the sample period into four periods: 1991-1995, 1996-2000, 2001-2005, and 2006-2010. ${ }^{23}$ We take the natural log of variables other than dummies. We use 85 countries. $^{24}$

${ }^{20}$ File POP/15-1: Annual total population (both sexes combined) by five-year age group, major area, region and country, 1950-2100 (thousands).

${ }^{21}$ We use the simple mean applied tariff rate, which is the unweighted average of effectively applied rates for all products subject to tariffs calculated for all traded goods (Indicator Code: TM.TAX.MRCH.SM.AR.ZS). When the effectively applied rate is unavailable, the most favored nation rate is used instead. See http://data.worldbank.org/indicator/TM.TAX.MRCH.SM.AR.ZS for details.

${ }^{22}$ In Russia, the imports from 1991 to 1995 are reported to be zero. If it is not correct, the reported openness may be lower than the actual level. However, the empirical results excluding Russia are hardly different from the results described in the text.

${ }^{23}$ In Figures 3-8 and Tables 1-3, A3, and A4, all variables from 1991-2010 are calculated as average of preceding five years. For example, the trade openness in 1995 means the mean of the trade openness from 1991 to 1995.

${ }^{24}$ If there is a missing value in any period, we do not include the country in the sample. Sample countries are listed in Table A1. Sample countries and periods are limited due to 
Figure 3 plots the logarithm of the share of the working-age population in a total population and the logarithm of trade openness of the sample. This figure indicate that the share of the working-age population and trade openness are positively correlated. Moreover, both of them are increasing as time passes. The data illustrated in Figure 3 thus support our hypothesis. $^{25}$

\section{$<$ Insert Figure $3>$}

\section{Estimation Results}

Based on the discussion in Section 3, we conduct the empirical analyses setting trade openness as the dependent variable and variables of age structure, tariff rates, population, the government consumption's share of GDP, and the period dummies for 2000, 2005 and 2010 as the independent variables. Figure 3 shows the positive relationship between the share of the working-age population and trade openness, but it is possible that the results for the effect of age structure on trade openness are sensitive depending on the independent variables. To check the robustness of our estimation, we estimate the equation without

the lack of the data of tariff rates. Table A2 presents the descriptive statistics of the data used in our empirical analysis.

${ }^{25}$ Data of El Salvador are available except 85 countries. However, logged trade openness of El Salvador is extremely large for the logged share of working-age population in total population in the all four points, i.e., (the logarithm of share of working-age population, the logarithm of trade openness $)=(-0.600,0.790),(-0.581,1.338),(-0.558,1.875),(-0.512$, 2.403). Thus, El Salvador suspected to be outlier and we conduct the empirical analysis with 85 countries, excluding El Salvador. 
including population, the share of the government consumption in GDP, and period dummies. ${ }^{26}$ It is possible for the empirical results of fixed-effects and random-effects models to differ greatly, and thus we report results of both models.

Table 1 presents the estimation results when the share of working-age population (population from 15 to 64 years old) in a total population represents the variable of age structure. The coefficients of the variable of age structure are positive and statistically significant for all estimations. All of the estimated effects of tariff rate are negative, and this is consistent with our hypothesis but the coefficient is not statistically significant in the fixed-effects model with period dummies. The coefficients of the share of government consumption in GDP are negative in all estimations and are significant except in the fixedeffects model with period dummies. The coefficients of population are all significant in all results. The coefficient is positive in the fixed-effects estimation without period dummies and is negative in any other estimation. The coefficients of the period dummies for 2000, 2005 and 2010 are all significantly positive and are gradually higher for recent years. In Table 1, the fixed-effects model is supported by the result of the Hausman test.

< Insert Table 1 >

\footnotetext{
${ }^{26}$ As is expected from Figure 3, the results about the effects of age structure on openness are consistent with our hypothesis even when we exclude tariff rates. Details about the empirical results are described in footnote 27.
} 
Table 2 shows the results when the share of population from 25 to 49 years old is used for the variable of age structure. According to the result of the Hausman test, the fixedeffects model is supported. All of the estimated coefficients of the variable of age structure are positive and significant. The estimated coefficients of age structure in Table 2 are a little smaller than those in Table 1. Judging from the signs and statistical significance of the estimated coefficients of independent variables other than age structure, the results in Table 2 are not very different from those in Table 1.

\section{$<$ Insert Table 2 >}

Table 3 presents the estimation results for the case in which the variables of age structure are the share of the young-dependent population (population from 0 to 14 years old) and the share of old-dependent population (population of 65 years and older). The estimated coefficients of the shares of the young- and old-dependent populations are significantly negative for all estimations. The coefficients of the share of old-dependent population (population of 65 years and older) in a total population are also negative and significant for all specifications. The estimated coefficients indicate that an increase in the share of population from 0 to 14 years old decreases trade openness more than that in the share of population of 65 years and older. In the fixed-effects model with period dummies, the coefficient of population is positive but insignificant. Except for this, the results of Tables 1 and 3 are not very much different, judging from the signs and statistical 
significance of the estimated coefficients of the independent variables other than age structure. In Table 3, the fixed-effects model is supported by the result of the Hausman test.

$<$ Insert Table $3>$

Here, we discuss the effects of age structure, tariff rates, the share of the government consumption of GDP, population, and period dummy variables on trade openness based on the results provided in Tables 1-3. The coefficients of variables for age structure demonstrate that an increase in the share of the working-age (dependent) population increases (decreases) trade openness regardless of the estimation methodologies or variables included in the regression. ${ }^{27}$ This is consistent with our hypothesis discussed in

\footnotetext{
${ }^{27}$ To check whether the estimated results of age structure are robust, we conducted empirical analyses changing independent variables. In Table A3, the logarithm of real GDP is used for the variable of country size in place of the logarithm of population. We use the data of real GDP (Indicator Code: rgdpo), which are obtained from Penn World Table 8.0. Judging from the signs and statistical significance of the estimated coefficients of variables for age structure, the results in Table A3 are not very different from those in Tables 1 and 3. The coefficients of real GDP are all significant in all results. The coefficients are positive in the fixed-effects estimations without period dummies and are negative in other estimations. Therefore, the sign of the effect of country size on trade openness is not definite in the case of either population or real GDP. According to Table A4, the coefficients of the share of old-dependent population is negative but insignificant in the fixed-effects model without period dummies. Except for this, our hypothesis is supported even when tariff rate is not included in the independent variables. We do not report the results using the share of
} 
Section 2 . Tables 1 and 2 imply that the share of population from 15 to 64 years old has a larger effect on trade openness than the share of population from 25 to 49 years old. It is possible that working-age population other than population from 25 to 49 years old also has an important influence on trade openness. According to Table 3, the share of youngdependent population has a greater effect than the share of old-dependent population. This is consistent with Braude's (2000) point that the share of expenditures for service in the total consumption by young generation tends to be higher than that by old generation.

All of the estimates of tariff rates are negative, and its coefficients are significant in the results except in the fixed-effects model with period dummies. Therefore, the decrease in the tariff rate could increase trade openness, which is consistent with our hypothesis.

All of the estimated coefficients of the share of government consumption in GDP are negative and most of them are significant. Our empirical results support those of Benarroch and Pandey (2008) to some extent. Rogoff (1992) pointed out that the share of expenditures for domestic goods in a total government expenditure tends to be higher than the share of expenditures for domestic goods in a total private expenditure. If an expansion of government size does not increase domestic production, an increase in domestic demand induced by an increase in government size can decrease the exports of domestic products. As a result, it might decrease trade openness. ${ }^{28}$

population from 25 to 49 years old in Tables A3 and A4 because the results are not very different from those using the share of population from 15 to 64 years old.

${ }^{28}$ If an expansion of government size increases domestic production, the negative effect of government size on trade openness would be restrictive. 
Most estimated coefficients of population are significantly negative, and this is consistent with Alesina and Wacziarg (1998). However, the estimated coefficient of population is significantly positive in the fixed-effects model without period dummies in Tables 1-3 and is insignificant but positive in the fixed-effects model with period dummies in Table 3. Ram (2009) pointed out that the estimated coefficient of population is positive in the fixed-effects model, and we cannot clarify the effect of population on trade openness.

Period dummies are positive and significant. Moreover, the coefficients of period dummies are gradually increasing. From the latter half of the 20th century to the beginning of the 21 st century, transportation cost decreased due to technological progress, and the foreign outsourcing of multinational companies has been stimulated in not only developed countries but also developing countries. It is plausible that the estimates of period dummies are larger for later periods due to these factors.

\section{Simulation results}

In this section, based on our estimated results of the effect of age structure on trade openness, we simulate trade openness based on age structure not only in the estimation period (1991-2010) but also in the future (2015-2100). It is possible that each generation's share of consumption for tradable and non-tradable goods in total consumption changes because new kinds of tradable and non-tradable goods may come into markets. However, we believe that the share of working-age (dependent) population will keep having a positive (negative) impact on trade openness in the future. In fact, dependent population tend to consume more non-tradable goods such as childcare, education, nursing care and 
medical services than working-age population, and it is not expected that these services will become perfectly tradable in the future. In addition, it is unlikely that the share of expenditures of non-tradable goods in the total expenditure of working-age population is higher than that for dependent population.

World Population Prospects: The 2012 Revision, DVD Edition by the United Nations, Department of Economic and Social Affairs, Population Division reports eight types of projected variables for age structure (Medium fertility, High fertility, Low fertility, Constant fertility, Instant replacement, Zero migration, Constant mortality, and No change) from 2015 to $2100 .{ }^{29}$ The United Nations calculated projected population of medium variant fertility (Medium fertility) based on their own methodology considering the stages of demographic transition. The High fertility (Low fertility) scenario assumes higher (lower) fertility than the scenario of Medium fertility. Under the Constant fertility assumption, fertility remains constant at the level estimated for 2005-2010. Under the Instant replacement assumption, fertility is set to the level necessary to ensure a net reproduction rate of 1 starting in 2010-2015 for each country. In the Zero migration variant, international migration is set to zero starting in 2010-2015. The Constant mortality variant assumes that mortality is constant at the level estimated for 2005-2010. The No change variant has the same international migration as the medium variant but differs from the latter by having constant fertility and mortality. ${ }^{30}$ Some cases might be too extreme to

\footnotetext{
${ }^{29}$ File POP/7-1: Total population (both sexes combined) by five-year age group, major area, region and country, 1950-2100 (thousands).

${ }^{30}$ For details, see the United Nations (2013b, Chapter V).
} 
realize. However, the simulation results can lead to policy implications about trade openness in the future if the simulated effects of these eight types of age structure on trade openness have similar characteristics.

In the simulation analysis, for the data of 1991 to 2010 , we use the natural log of the variables of age structure in Section 4. For the data of the future (2015-2100), we take the natural log of the projected variables of age structure every five years. ${ }^{31} \mathrm{We}$ calculate the product of the mean of each logged variable for age structure of 85 countries and the coefficient of the variable for age structure estimated in Section 4 in each period. We set the product in the first period as the benchmark and express the change of the effect of age structure on trade openness as differences between the benchmark and the products of other periods: 2000-2100. Moreover, we use the natural log of trade openness in Section 4 for the data of 1991 to 2010 and discuss how much age structure contributes to the increase in the trade openness. We calculate the mean of the logged trade openness of 85 countries in each period, set the mean in the first period as the benchmark and express the change of the trade openness as differences between the benchmark and the means of other periods: 2000-2010. Figures 4-7 show the effects of the components of age structure on trade openness, and Figure 8 presents the effects of age structure on trade openness considering the information presented in Figures 4, 6, and 7.

\footnotetext{
${ }^{31}$ As well as in Section 4, we use the observed five-year average data from 1991 to 2010 because the tentative shock might influence the results greatly. For the projected data from 2015 to 2100 , we use the data of every five years because there is no outlier.
} 


\section{$<$ Insert Figure 4 >}

The variable of age structure in Figure 4 is the share of the working-age population, and we use its estimated coefficient in Table $1 .{ }^{32}$ The simulated trade openness based on working-age population will increase until the beginning of the 21 st century and will decrease after that. The reason for this is that the share of the working-age population in the total population will peak in the first half of the 21 st century and will decrease after the peak. In the latter half of the 21 st century, trade openness is estimated to be lower than that in the 1990s except for the case of constant mortality. In the case of low fertility, workingage population will keep increasing trade openness until the 2020s but decrease it more than the other seven cases at the end of the 21 st century.

\section{$<$ Insert Figure $5>$}

In Figure 5, we use the share of population from 25 to 49 years old as the variable for age structure, and we adopt its coefficient in Table 2. Figure 5 is similar to Figure 4, but Figure 5 shows that all of the types of simulated trade openness in the latter half of the 21 st century will be less than that in the first half of the 1990s.

\footnotetext{
${ }^{32}$ In the simulation, we use the estimated results of the model that includes all of the explanatory variables. We select the results of the fixed-effects model based on the Hausman test. Likewise, we select the estimates of the fixed-effects model based on the Hausman test for Figures 5-7.
} 


\section{$<$ Insert Figure 6 >}

In Figure 6, the variable of age structure is the share of the young-dependent population, and we use its estimated coefficient in Table 3. The change of the youngdependent population is estimated to contribute to the increase in trade openness because the share of the young-dependent population continues to decrease even in the case of high fertility. The simulated trade openness based on the young-dependent population will vary considerably depending on the projected patterns. This suggests that the changes in the share of young-dependent population will greatly influence trade openness in the future.

\section{$<$ Insert Figure $7>$}

In Figure 7, the share of old-dependent population is used as the variable for age structure, and we adopt its coefficient according to Table 3. It is expected that the share of old-dependent population will keep increasing under any of the eight types of population projection, and the changes in the old-dependent population has decreased trade openness and will continue to decrease it throughout the 21 st century.

\section{$<$ Insert Figure $8>$}

In Figure 8, the share of young-dependent population, the share of working-age population, and the share of old-dependent population are considered as the variables for 
age structure. The coefficients of the variables for age structure follow Figures 4, 6, and 7. In addition, Figure 8 demonstrates the changes in the observed trade openness from 1991 to 2010. Figure 8 shows that the observed trade openness and simulated trade openness increased throughout that period. It is considered that age structure thus contributed to an increase in trade openness. This figure shows that the simulated trade openness in the quite near future will be different depending on the projection pattern, mainly because of the difference in the young-depend population share. In the case of low fertility, the change of age structure is estimated to raise trade openness from the 1990 s to the 2020 s with almost the same trend. In the case of high fertility, it appears that the change in age structure will decrease trade openness rapidly and that the simulated trade openness in the 2020s will be almost the same as that in the 1990s. In the six cases other than the abovementioned two extreme cases, the simulated trade openness will be stable until the 2030s. However, in the all cases, the simulated trade openness is estimated to start decreasing by the middle of the 21 st century. At the end of the 21 st century, the extent of the effect of age structure on trade openness will be similar to that of the 2000s (1990s) for the cases of low fertility (constant mortality), but is estimated to be less than the extent of the 1990s for the other six cases. According to our simulation results, changes in age structure currently increase trade openness but will decrease it in the future.

\section{Conclusions}

We found that an increase in the share of the working-age population (dependent population) in a total population can raise (lower) trade openness, based on our estimation 
results. The simulation results implies that changes in age structure, especially increases in the share of the working-age population, will increase trade openness until the beginning of the 21 st century. On the other hand, in any simulation results, changes in age structure will decrease trade openness by the 2030 s and will continue to decrease it after that. According to the any types of projected age structure described by the United Nations, the share of the world's young-dependent population is going to decrease and the share of the olddependent population is going to increase. On the other hand, the increase in the share of the working-age population is projected to peak in the first half of the 21 st century. Decreases in the share of the young-dependent population will increase trade openness to some extent, but decreases in the share of the working-age population and increases in the share of the old-dependent population will greatly decrease trade openness.

We do not deny that policy-led trade liberalization, technology-led falling transportation costs, and foreign outsourcing were also important factors in the increase in trade openness by the beginning of the 21 st century. Even today, the number of countries affiliated with the WTO continues to rise, and many countries have been seeking new FTA partners. Technological progress has also decreased transportation costs. Moreover, many multinational companies have expanded their business to emerging countries. It is thus expected that these factors will continue to raise trade openness throughout the 21 st century. In addition, non-tradable goods may become tradable thanks to technological progress. Therefore, even if the share of the working-age population in a total population becomes the same level as that in the 1990s in the future, trade openness might not become so. 
References

Alesina, A., and R. Wacziarg (1998) Openness, country size and government, Journal of Public Economics, vol. 69, pp. 305-321.

Baier, S. L. and J. H. Bergstrand (2001) The growth of world trade: tariffs, transport costs, and income similarity, Journal of International Economics, vol. 53, pp. 1-27.

Barro, R. J. (2000) Inequality and Growth in a Panel of Countries, Journal of Economic Growth, vol. 5, pp. 5-32.

Benarroch, M. and M. Pandey (2008) Trade openness and government size, Economics Letters, vol. 101, pp. 157-159.

Benarroch, M. and M. Pandey (2012) The relationship between trade openness and government size: Does disaggregating government expenditure matter? Journal of Macroeconomics, vol. 34, pp. 239-252.

Bordo, M. D. (2002) Globalization in Historical Perspective: Our era is not as unique as we might think, and current trends are not irreversible, Business Economics, pp. 20-29.

Braude, J. (2000) Age Structure and the Real Exchange Rate, Bank of Israel Discussion Paper Series 2000.10.

Cameron, D. R. (1978) The expansion of the public economy: A comparative analysis, American Political Science Review, vol. 72, pp. 1243-1261.

Davis, D. R. (1995) Intra-industry trade: A Heckscher-Ohlin-Ricardo approach, Journal of International Economics, vol. 39, pp. 201-226. 
Dornbusch, R., S. Fischer and P. A. Samuelson (1977) Comparative Advantage, Trade, and Payments in a Ricardian Model with a Continuum of Goods, The American Economic Review, vol. 67, pp. 823-839.

Fair, R. C. and K. M. Dominguez (1991) Effects of the changing U.S. age distribution on macroeconomic equations. American Economic Review, vol. 81, pp. 1276-1294.

Feenstra, R.C. (1998) Integration of trade and disintegration of production in the global economy, Journal of Economic Perspectives, vol. 12, pp. 31-50.

Ferrero, A. (2010) A structural decomposition of the U.S. trade balance: Productivity, demographics and fiscal policy, Journal of Monetary Economics, vol. 57, pp. 478-490.

Fry, M. J. and A. Mason (1982) The Variable Rate-of-Growth effect in the Life-Cycle Saving Model, Economic Inquiry, vol. 20, pp. 426-442.

Garen, J. and K. Trask (2005) Do more open economies have bigger governments? Another look, Journal of Development Economics, vol. 77, pp. 533-551.

Garrett, G. (2001) Globalization and government spending around the world. Studies in Comparative International Development, vol. 35, pp. 3- 29.

Greenaway, D. and C. Milner (1986) The Economics of Intra-industry Trade, Basil Blackwell.

Helpman, E. (1981) International Trade in the Presence of Product Differentiation, Economies of Scale and Monopolistic Competition: A Chamberlin-Heckscher-Ohlin Approach, Journal of International Economics, vol. 11, pp. 305-340.

Helpman, E. and P. Krugman (1985) Market structure and foreign trade, Cambridge: MIT Press. 
Herbertsson, T. T. and G. Zoega (1999) Trade surpluses and life-cycle saving behavior, Economics Letters, vol. 65, pp. 227-237.

Higgins, M. (1998) Demography, national savings, and international capital flows, International Economic Review, vol. 39, pp. 343-369.

Hill, J. K. (1989) Demographics and the trade balance, Economic Review (Federal Reserve Bank of Dallas), September, pp. 1-11.

Hurd, M. D. (1990) Research on the Elderly: Economic Status, Retirement, and Consumption and Saving, Journal of Economic Literature, vol. 28, pp. 565-589.

Islam, M. Q. (2006) The long run relationship between openness and government size: evidence from bounds test, Applied Economics, vol. 36, pp. 995-1000.

Kinugasa, T. and A. Mason (2007) Why Countries Become Wealthy: The Effects of Adult Longevity on Saving, World Development, vol. 35, pp. 1-23.

Krugman, P. (1979) Increasing returns, monopolistic competition, and international trade Journal of International Economics, vol. 9, pp. 469-479.

Krugman, P. (1995) Growing world trade: Causes and consequences. Brookings Papers on Economic Activity, No. 1, pp. 327-377.

Lee, R., A. Mason, and members of the NTA Network (2014) Is low fertility really a problem? Population aging, dependency, and consumption, Science, vol. 346, pp. 229-234.

Lindh, T. and B. Malmberg (1998) Age structure and inflation - a Wicksellian interpretation of the OECD data, Journal of Economic Behavior \& Organization, vol. 36, pp. 19-37. 
Lindh, T. and B. Malmberg (1999) Age structure effects and growth in the OECD, 1950-1990, Journal of population Economics, vol. 12, pp. 431-449.

Mason (1987) National saving rates and population growth: a new model and new evidence." In Johnson, D. G. and R. Lee (eds.), Population Growth and Economic Development: Issues and Evidence, University of Wisconsin Press.

Mason (1988) Saving, Economic Growth, and Demographic Change.” Population and Development Review, vol. 14, pp. 113-44.

Modigliani, F. and R. Brumberg (1954) Utility analysis and the consumption function: An interpretation of cross-section data, In Kurihara, K. (ed.), Post-Keynesian Economics, Rutgers University Press.

Poterba, J. M. (2001) Demographic Structure and Asset Returns, Review of Economics and Statistics, vol. 83, pp. 565-584.

Ram, R. (2009) Openness, country size, and government size: Additional evidence from a large cross-country panel, Journal of Public Economics, vol. 93, pp. 213-218.

Rodrik, D. (1998) Why do more open economies have bigger governments? Journal of Political Economy, vol. 106, pp. 997-1032.

Rogoff, K. (1992) Traded Goods Consumption Smoothing and the Random Walk Behavior of the Real Exchange Rate, BOJ Monetary and Economic Studies, vol. 10, pp. 129.

Rose, A. K., S. Supaat and J. Braude (2009) Fertility and the real exchange rate, Canadian Journal of Economics, vol. 42, pp. 496-518. 
Taylor, A. M. (1995) Debt, dependence and the demographic Transition: Latin America in to the next century, World Development, vol. 23, pp. 869-879.

Taylor, A. M. and J. G. Williamson (1994) Capital flows to the New World as an intergenerational transfer, Journal of Political Economy, vol. 102, pp. 348-371.

United Nations, Department of Economic and Social Affairs, Population Division (2013a) World Population Policies 2013, the United Nations, New York.

United Nations, Department of Economic and Social Affairs, Population Division (2013b) World Population Prospects: The 2012 Revision, Highlights and Advance Tables, Working Paper No. ESA/P/WP.228. 
Figure 1: Trade Openness in the World: 1950-2010

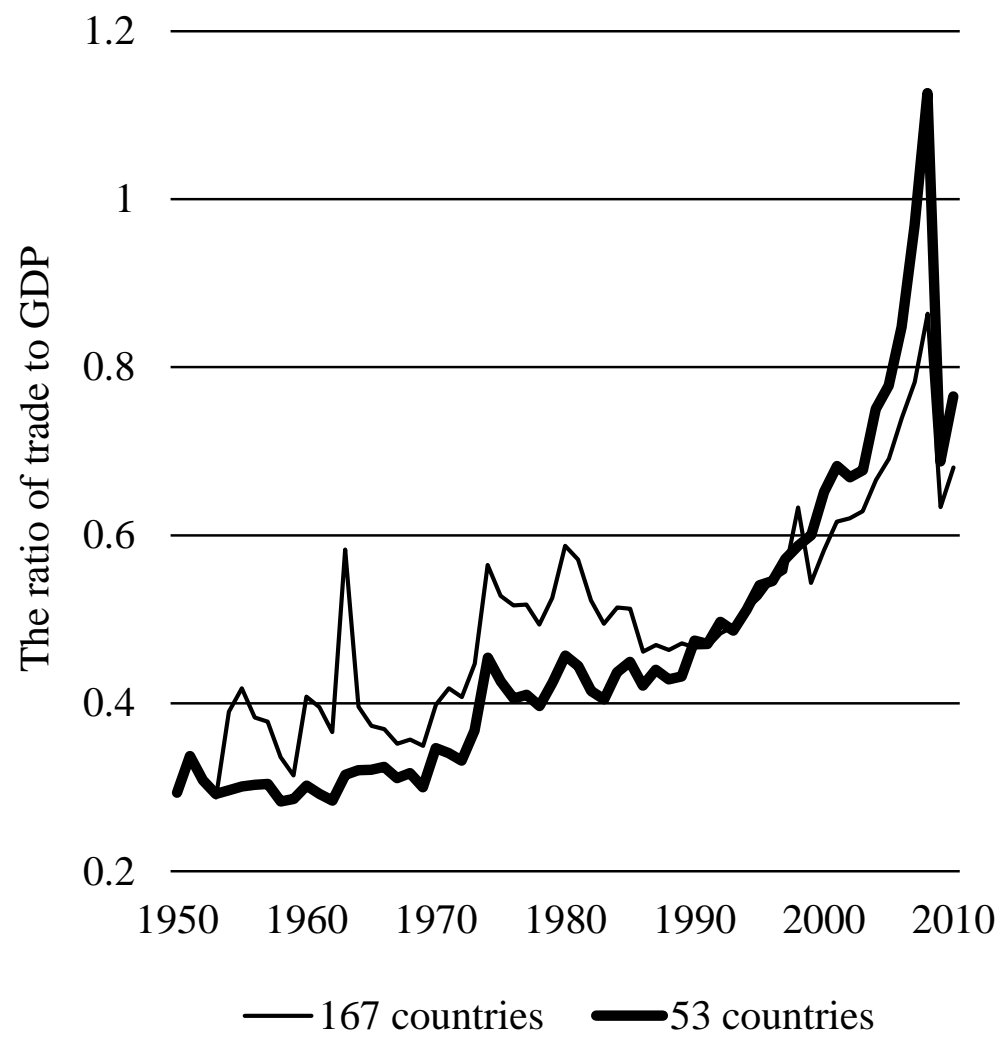

Note: The data source is Penn World Table 8.0 and is described in Section 3. The ratios of trade to GDP are calculated as simple arithmetic average values of sample countries every year. In this figure, we deal with 167 countries for which the data of trade openness are available. However, in the beginning period of the figure, the trade openness data are available for 53 countries. Therefore, we present two kinds of trade openness. 


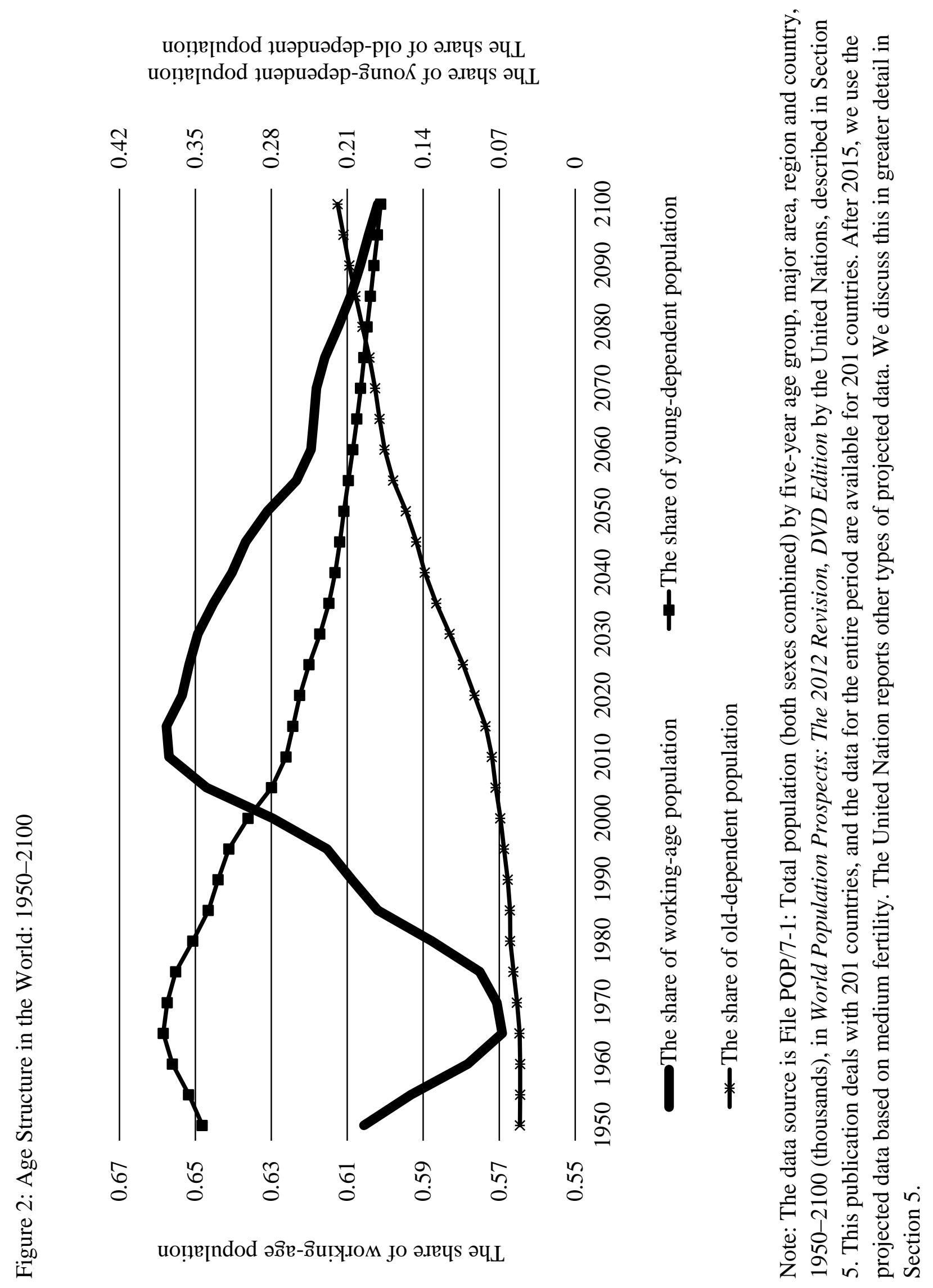


Figure 3: Scatterplots of Age Structure and Trade Openness

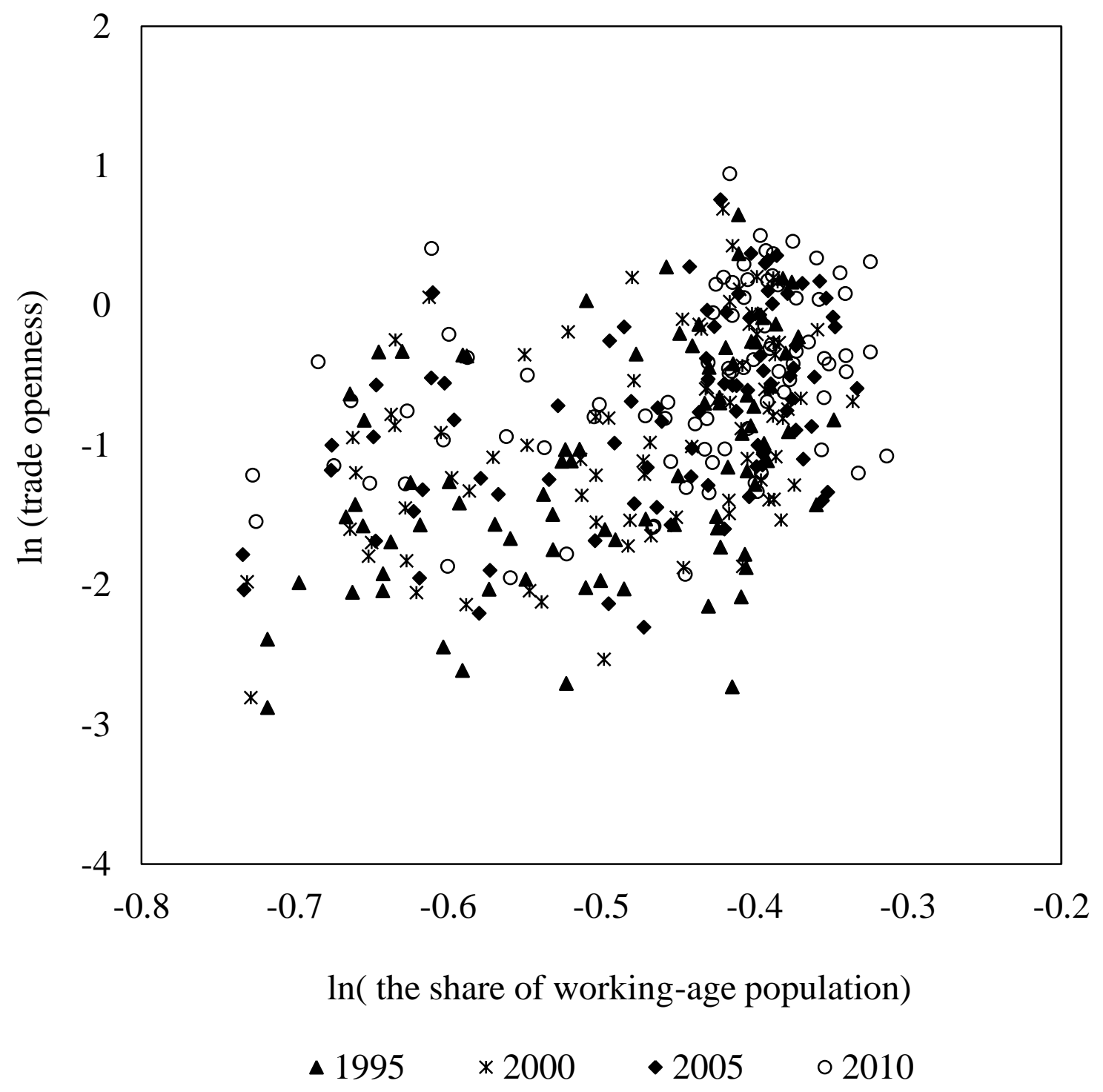

Note: Correlation coefficients are 0.434 in $1995,0.458$ in 2000, 0.478 in 2005, 0.404 in 2010 and 0.469 for the entire period. 

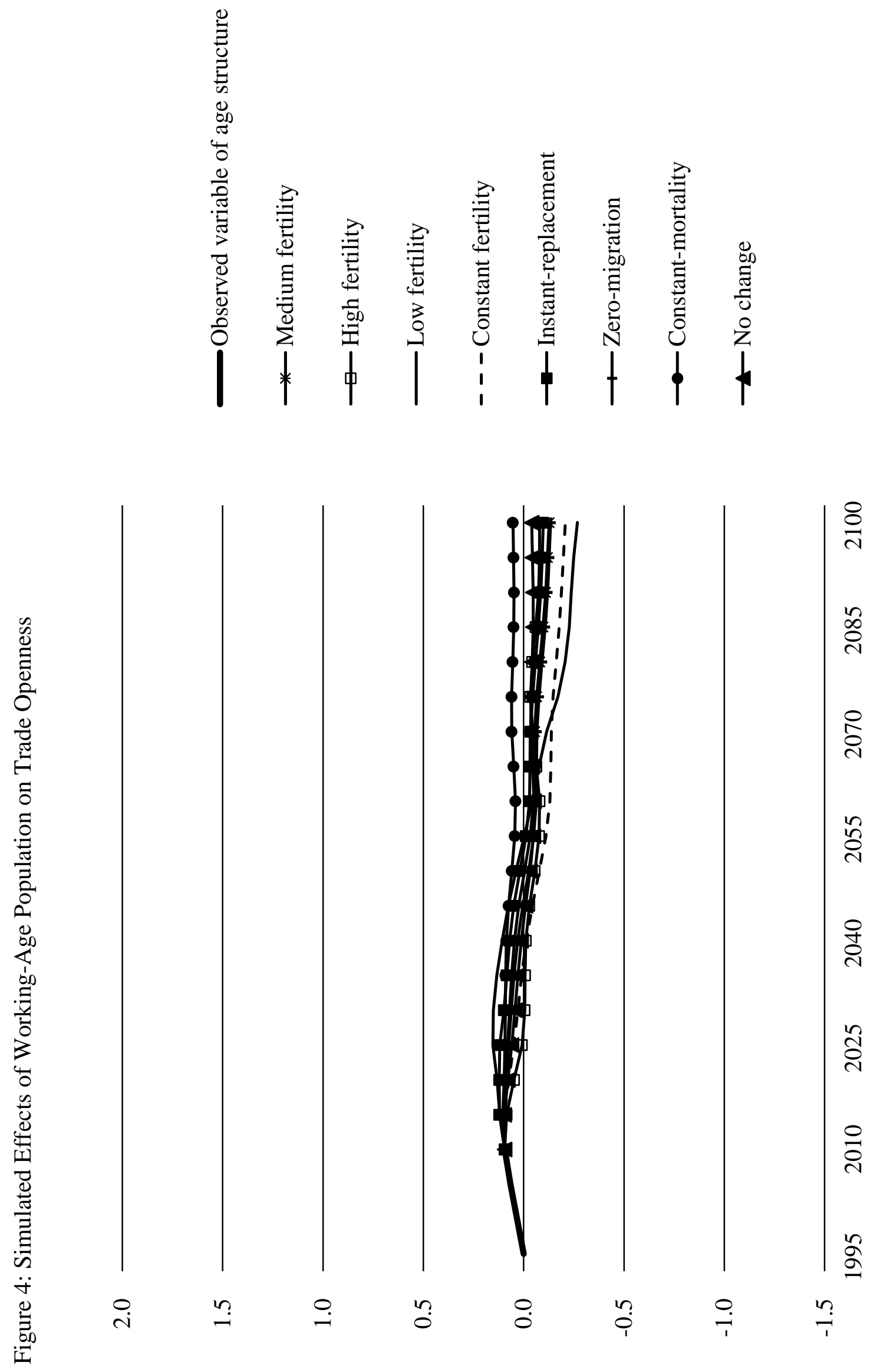

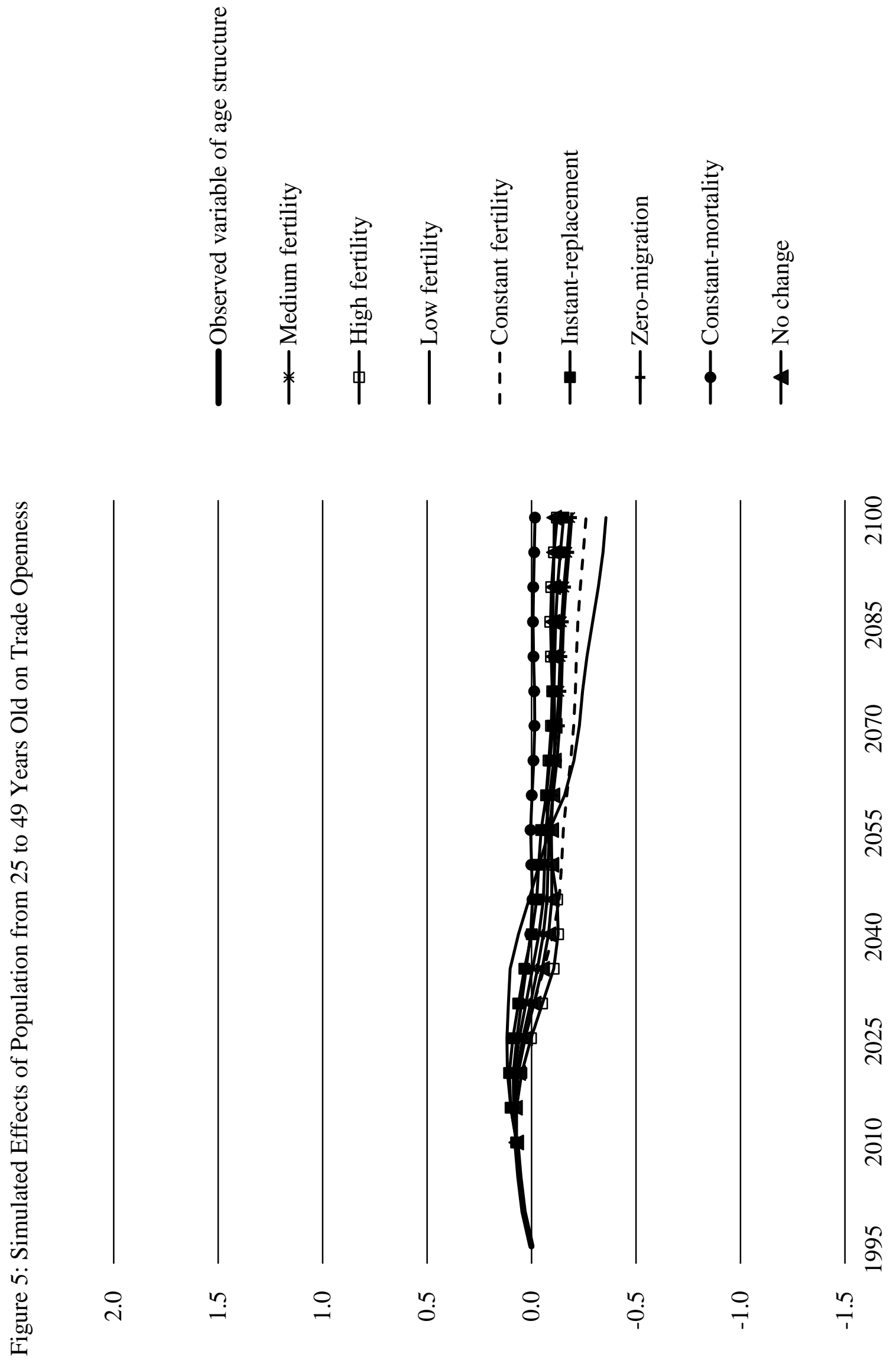

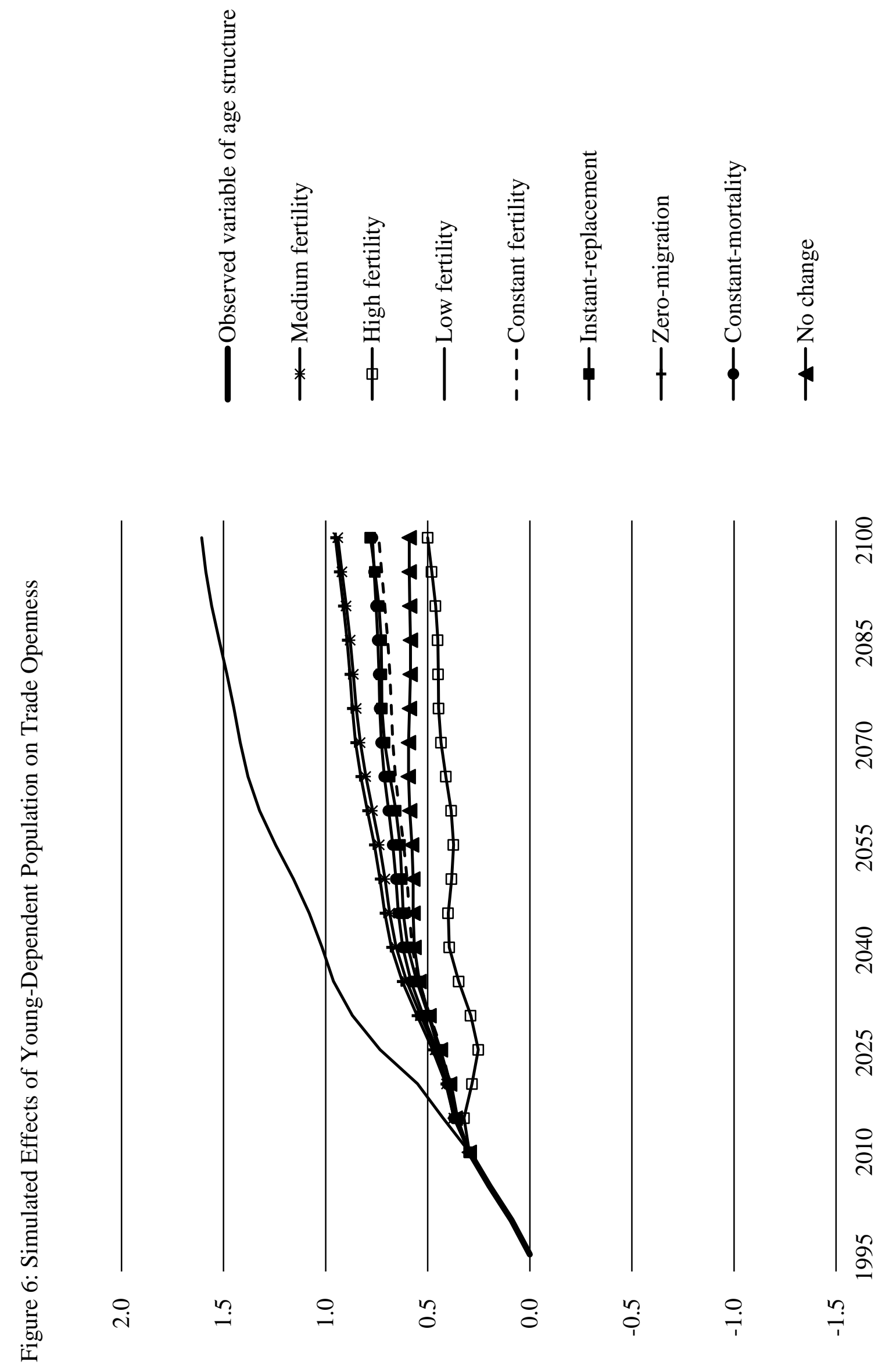

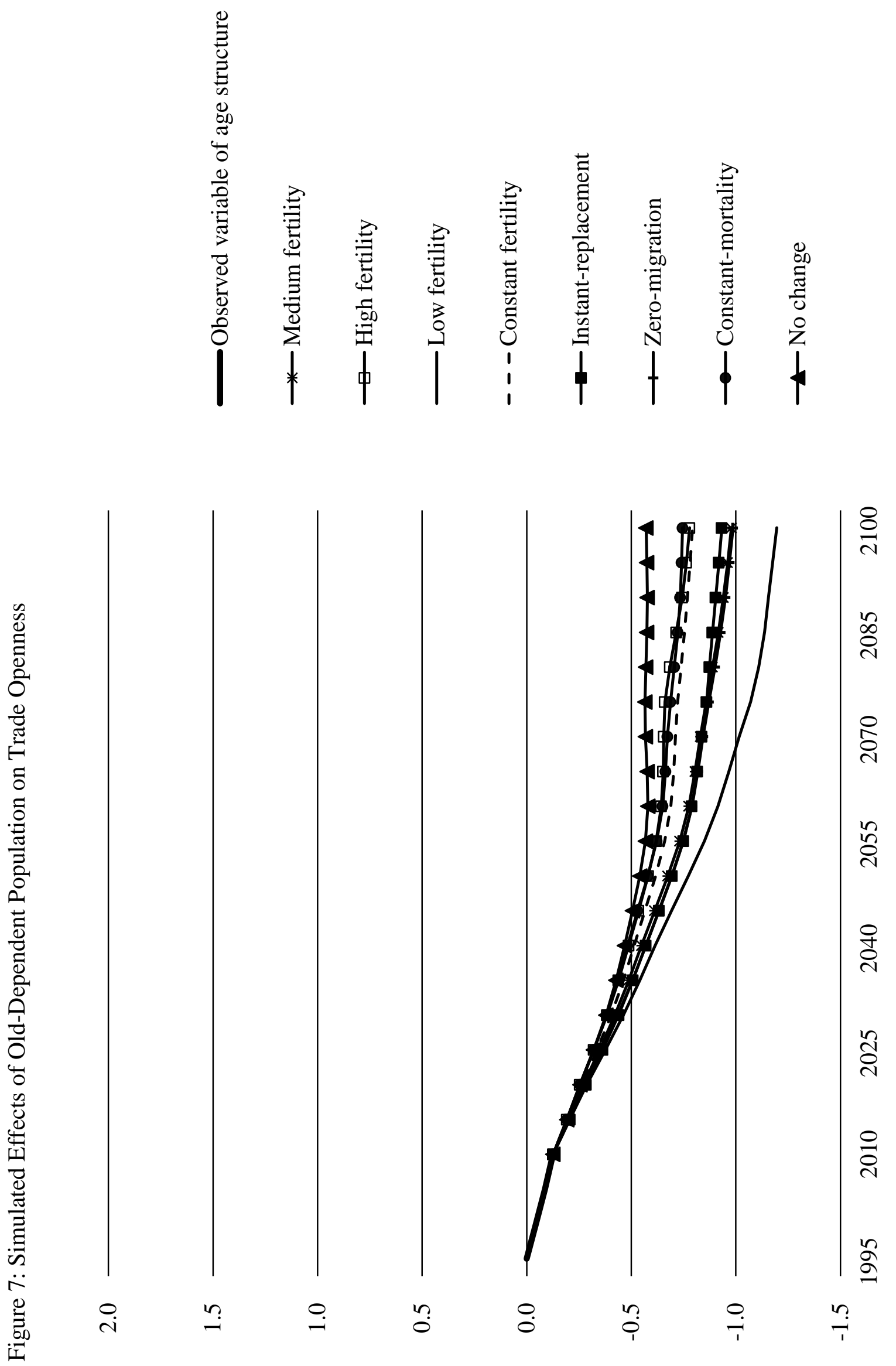


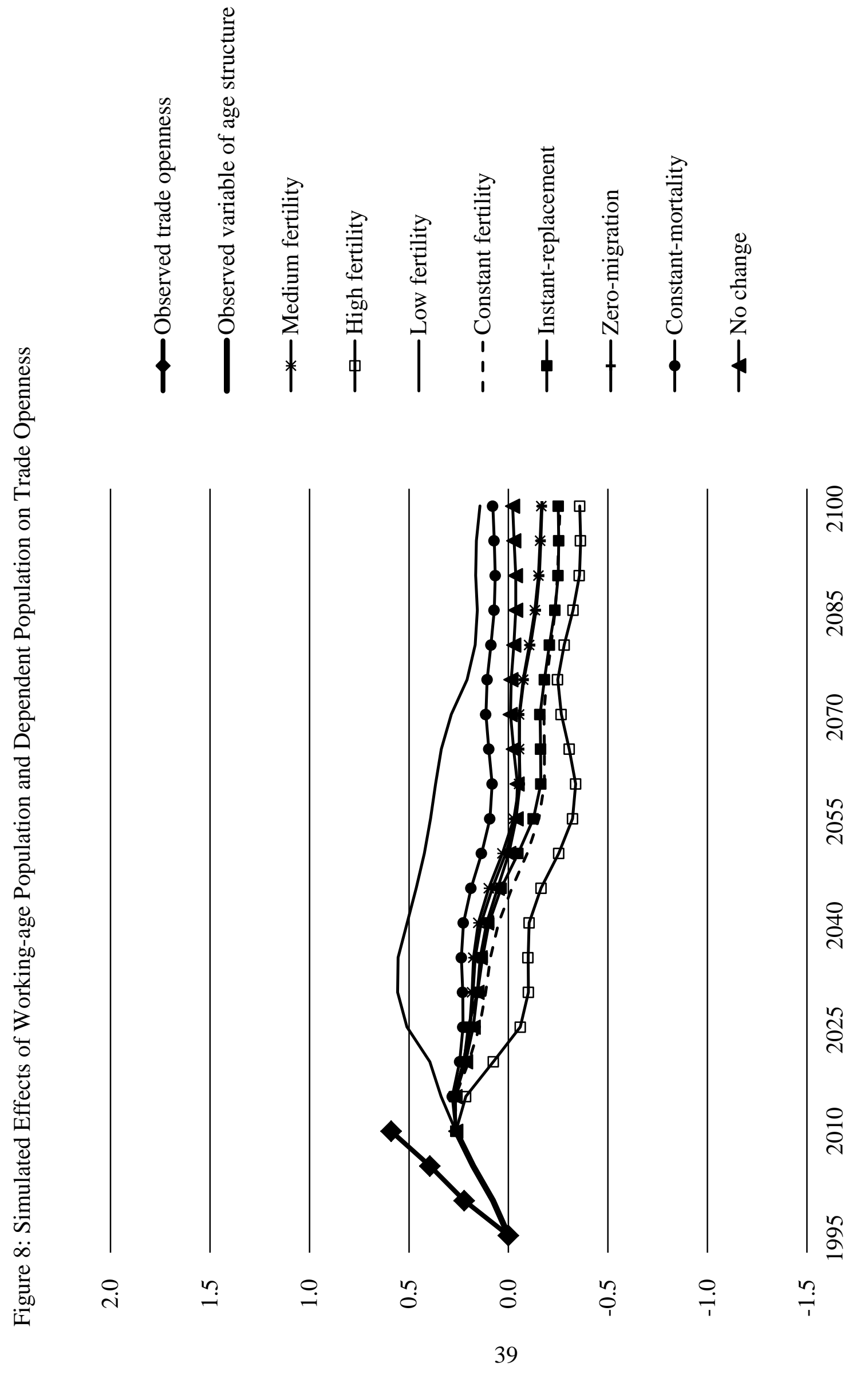




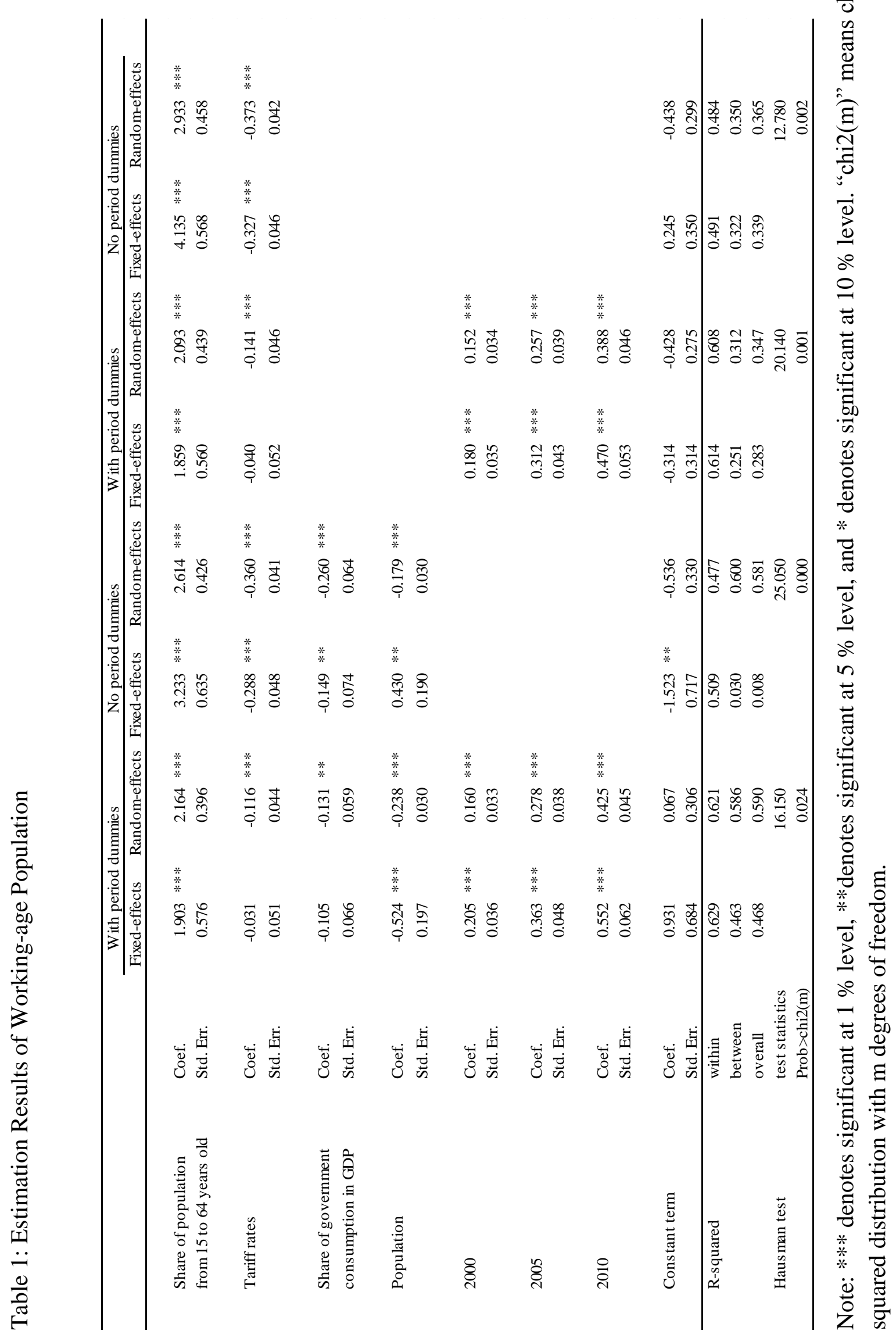




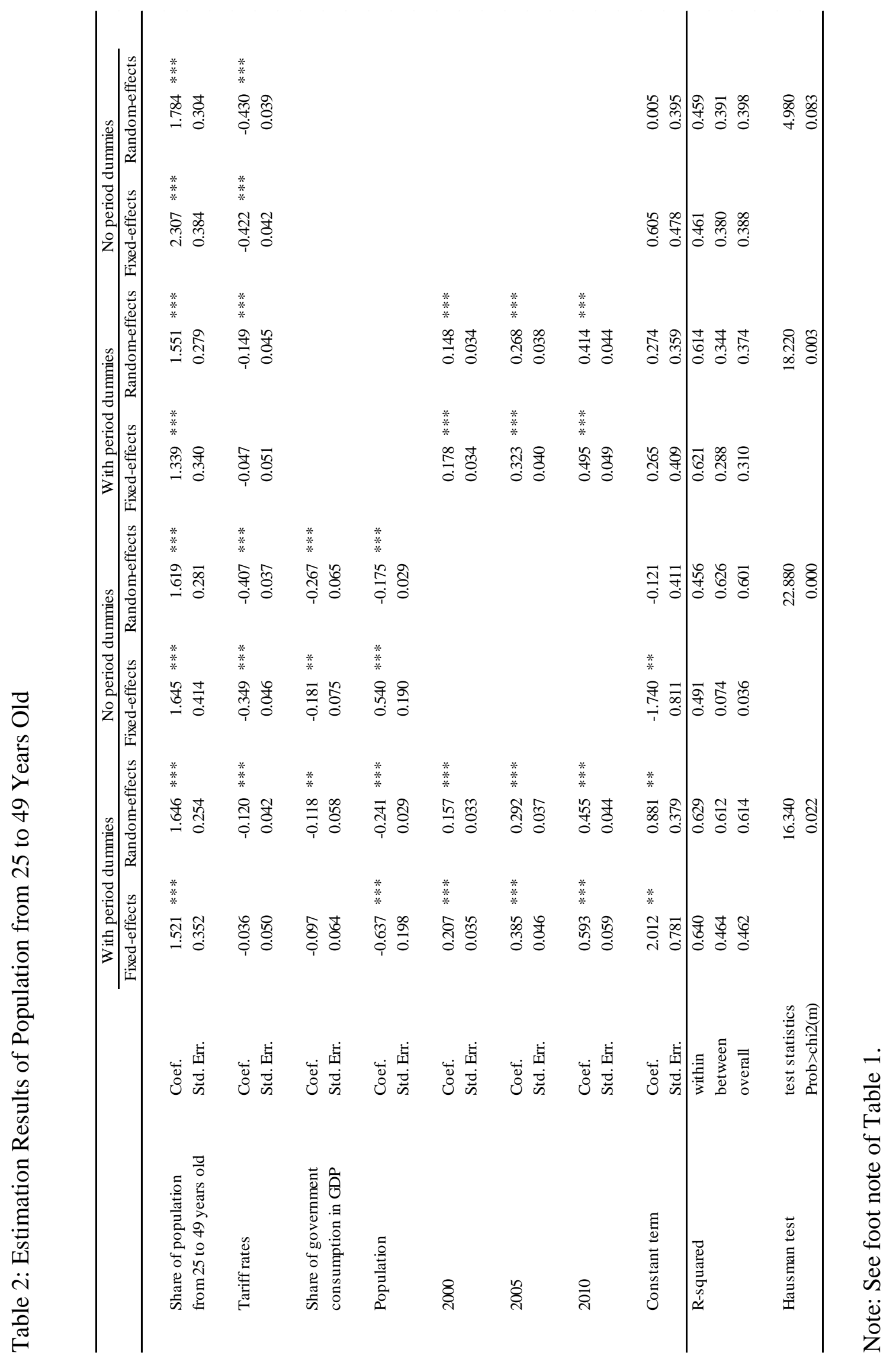




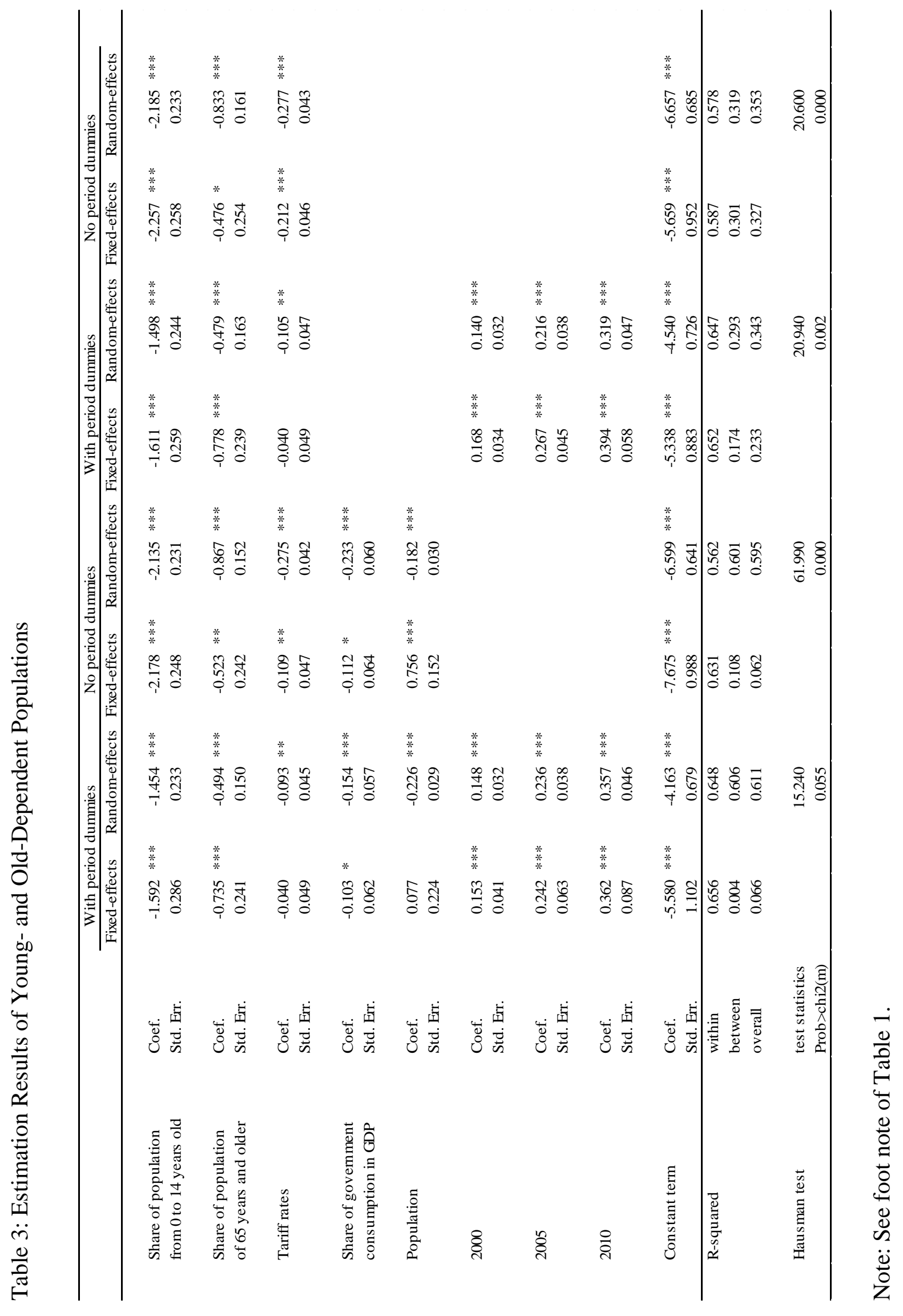


Table A1: List of countries

\begin{tabular}{|c|c|c|c|}
\hline & countries & & countries \\
\hline 1 & Argentina & 44 & Malta \\
\hline 2 & Australia & 45 & Mauritius \\
\hline 3 & Austria & 46 & Mexico \\
\hline 4 & Bangladesh & 47 & Morocco \\
\hline 5 & Belgium & 48 & Mozambique \\
\hline 6 & Bolivia & 49 & Nepal \\
\hline 7 & Brazil & 50 & Netherlands \\
\hline 8 & Bulgaria & 51 & New Zealand \\
\hline 9 & Canada & 52 & Nigeria \\
\hline 10 & Central African Republic & 53 & Norway \\
\hline 11 & Chad & 54 & Oman \\
\hline 12 & Chile & 55 & Pakistan \\
\hline 13 & China & 56 & Paraguay \\
\hline 14 & Colombia & 57 & Peru \\
\hline 15 & Costa Rica & 58 & Philippines \\
\hline 16 & Côte d'Ivoire & 59 & Poland \\
\hline 17 & Cyprus & 60 & Portugal \\
\hline 18 & Czech Republic & 61 & Republic of Korea \\
\hline 19 & Denmark & 62 & Republic of the Congo \\
\hline 20 & Ecuador & 63 & Romania \\
\hline 21 & Egypt & 64 & Russian Federation \\
\hline 22 & Estonia & 65 & Saudi Arabia \\
\hline 23 & Finland & 66 & Slovakia \\
\hline 24 & France & 67 & Slovenia \\
\hline 25 & Gabon & 68 & South Africa \\
\hline 26 & Germany & 69 & Spain \\
\hline 27 & Ghana & 70 & Sri Lanka \\
\hline 28 & Greece & 71 & Sweden \\
\hline 29 & Guatemala & 72 & Switzerland \\
\hline 30 & Honduras & 73 & Tanzania \\
\hline 31 & Hungary & 74 & Thailand \\
\hline 32 & Iceland & 75 & Trinidad and Tobago \\
\hline 33 & India & 76 & Tunisia \\
\hline 34 & Indonesia & 77 & Turkey \\
\hline 35 & Ireland & 78 & Uganda \\
\hline 36 & Italy & 79 & Ukraine \\
\hline 37 & Japan & 80 & United Kingdom \\
\hline 38 & Kenya & 81 & United States \\
\hline 39 & Latvia & 82 & Uruguay \\
\hline 40 & Lithuania & 83 & Venezuela \\
\hline 41 & Luxembourg & 84 & Vietnam \\
\hline 42 & Malawi & 85 & Zambia \\
\hline 43 & Malaysia & & \\
\hline
\end{tabular}




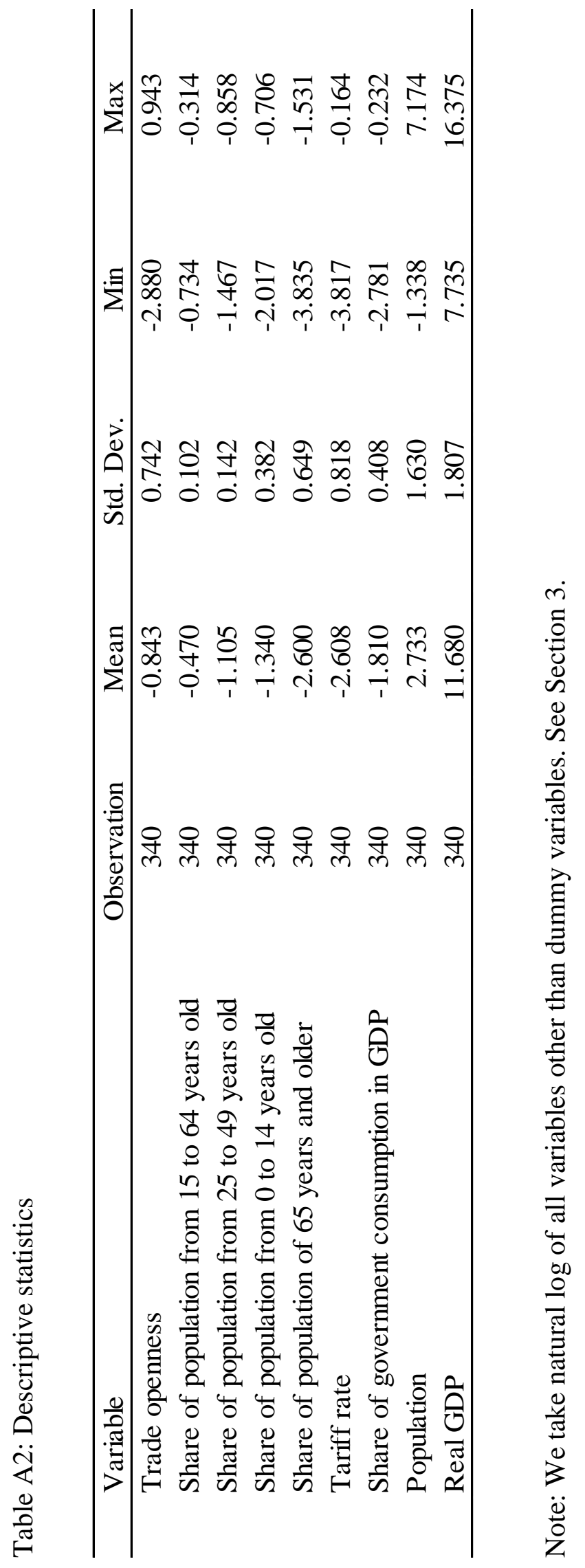




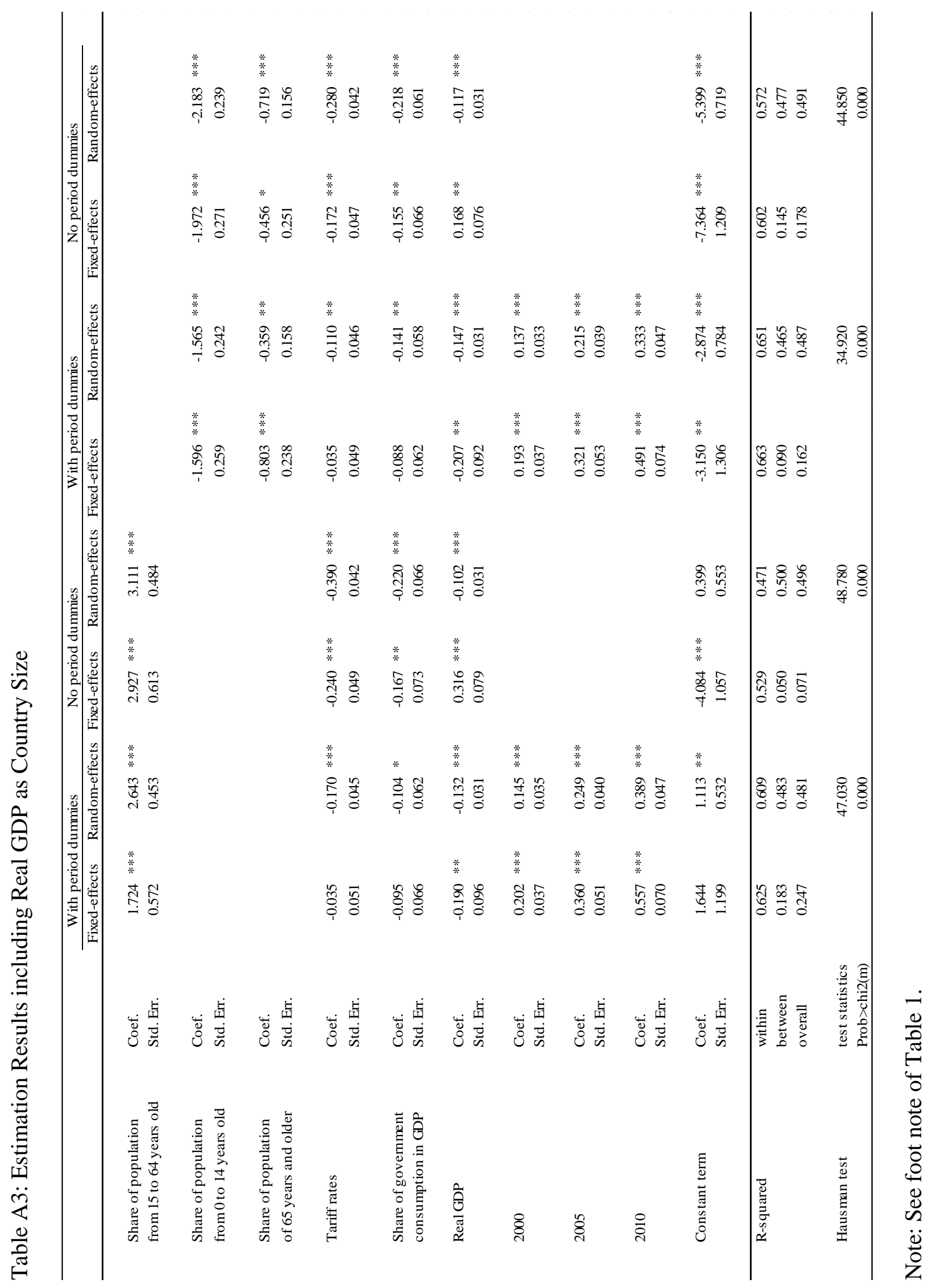




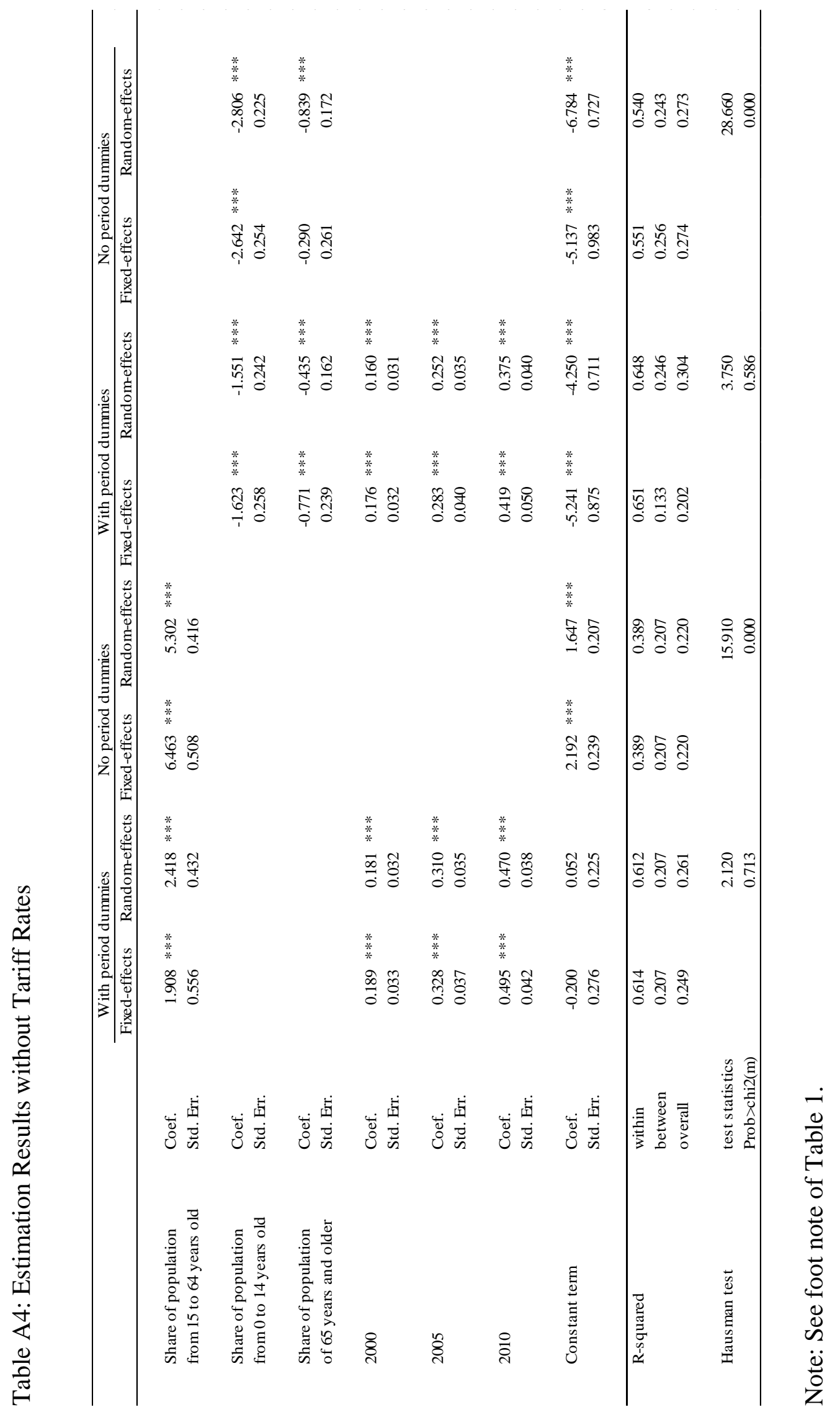

